\title{
D-batik: Development of Batik Motifs with Digital Techniques
}

\author{
Wandah Wibawanto ${ }^{1}$, Tjetjep Rohendi Rohidi ${ }^{2}$, Triyanto ${ }^{3}$ \\ \{wandah@mail.unnes.ac.id ${ }^{1}$,trrohidi@mail.unnes.ac.id ${ }^{2}$, triyanto@mail.unnes.ac.id ${ }^{3}$ \} \\ ${ }^{1,2,3}$ Arts Education Doctoral Degree Graduate Program Universitas Negeri Semarang
}

\begin{abstract}
The development of conventional batik motifs has not been able to meet the acceleration of the market which demands diverse batik motif designs. The development of batik motifs is easier to do with digital technology, but batik craftsmen in general are very unfamiliar with technology. This article seeks to describe the process of creating batik motifs through digital technology in the form of d-batik applications. D-Batik teknolayering from the method of creating conventional batik motifs. The study used qualitative methods with a case study approach. The research subjects were groups of Padalangan and Malon batik craftsmen who had used the d-batik application. The objects studied were the batik motifs produced, and the speed of production of batik motifs. The results show that the use of digital applications can accelerate the production of batik motifs and create new motive identities.
\end{abstract}

Keywords: batik, motifs, digital, technology.

\section{Introduction}

Trade in world apparel products reaching USD442 billion is a great opportunity for the batik industry to increase its market share, considering batik as one of the raw materials for apparel products. The export value of batik and batik products in October 2017 reached USD51.15 million, up from USD39.4 million in semester I 2017 [1]. The high demand for batik requires theBatik craftmen in Indonesia to compete in seizing domestic and foreign markets. In contrast, most of the batik produced by batik craftmen is traditionally managed. Most of the human resources that produce batik have the ability to make batik from generation to generation. Motive development is done conventionally by taking inspiration from conditions in the surrounding environment [2]. In several studies it was also found that batik craftmen were still unfamiliar with the use of digital technology in creating batik motifs [3].

The use of digital technology in production systems has been proven and tested to be able to reduce significantly the time needed by a designer in designing and developing a product when compared to conventional design processes [4]. Related to the use of technology in the creation of batik motifs, Wibisono and Toha have developed a CAD software ofbatik stamp for designing and coloring [5].The softwareuses thedatabasesystem of canting stampand thedatabaseof batik's color. Wyvill et al. in 2004 developed a digital batik system with a crack engineering simulation ("rendering cracks in batik"), the simulation results able to generatebatik's crack that could be formed according to the desires of the craftmentor customer. Hariadi in 2007 has also developed a softwarefor making batik designs, called fractal batik. It uses fractal mathematics throughFouriertransformation and produces a specific 
fractal based motif [6].

To operate those software, intermediate level is needed such as understanding the mathematical algorithms, creating curves (bezier) digitally, and operating applications that are relatively complex. Several studies have proven that the development of motives using applications can produce motive variations quickly, but the capability to operate the applications is a key factor in the successful creation of motives. In 2016 the Semarang City Ministry of Industry held training on for Batik craftmen, including production techniques and digitizing batik motifs. However, an interesting finding is that the complexity of graphic software actually slows down traditional batik craftsmen [7].

Therefore, in the following year an application was developed which aimed to facilitate the making of batik motifs, hereinafter referred to as D-batik. D-batik was developed using theSoftware Development Life Cycle (SDLC) method, with amodel approach prototypingthat simulates the traditional batik making process in digital form [8]. D-batik can be operated with an Android-based device that is quite commonly used in Indonesia [9].

The purpose of this article is to explore the application of D-batik, and the interactions that occur between users and applications. The article will also show a comparison between the process of making batik motifs traditionally and by using D-batik. The structure of paper is as follows: The Section 2 represents the methodology used in this research. Section 3 presents the features of D-batik and the drawing system. The last section provides some conclusions about the use of D-batik and the further research recommendation.

\section{Method}

The approach used in this study is digital ethnographic method. Digital anthropology focuses on the role of digital progress in changing the way people live the lives of certain groups [10]. Data collection techniques using field observations and questionnaires. Determination of research subjects or respondents in this study was conducted by purposive sampling [11], namely 20 craftsmen in the Semarang Malon Batik village and 20 craftsmen in the Pekalongan Kauman batik group. The age range is 45-50 years, and does not have a computer graphics education background. The variables observed included differences in the traditional development time and traditional motifs of batik, the characteristics of the motifs produced and the form of interaction between batik and application.

\section{Result and Discussion}

Innovation is the introduction of new discoveries or spreading the meaning of the new invention into public[12]. Schumpeter explains that innovation is seen as the creation and implementation of "new combinations" [13]. Innovation means the development and implementation of something new. Hamel says that the innovation strategy is not just the task of top management, but everyone can help build innovative strategies [14].

The creation of batik motifs are generally limited by time and financing, so craftsmen will only produce certain motifs or mimic popular motifs available on the market. The novelty in batik motifs becomes less rapid. In subsequent developments new motifs were developed by combining several existing motifs and creating new motifs with natural inspiration and objects around the craftsmen. Batik has certain ornaments that are geometric and non geometric. 
There are several groups in geometric patterns namely Ceplok, Kawung, Parang, Lereng, and Nitik. While non geometric motifs consist of Lung Lungan, Cement, Pagersari, Taplakand Wayangmotifs [15]. Geometric and non-geometric properties are facilitated in the D-Batik application.

D-Batikis a program to create batik motifs that are equipped with very simple UI that can be operated by people who are still unfamiliar with graphic technology. D-Batik simulates the technique of drawing traditional batik using a pencil stroke that is transformed in the form of a finger touch. The main features of the "D-Batik" application are drawing with "smooth and smart prediction curve"method that can be operated with a mouse or touch screen. This method is simplifying the digital drawing by transforming finger movement into smooth curve. "Tiling mode" feature, where repetition of patterns will be easier. "Symmetry draw" feature where the symmetry method is used to simplify the depiction of motifs based on angles. "Reflection" feature is a reflection mode for making symmetry motifs. "Quick View" feature is a mode for instantly displaying motifs. All of these features use Indonesian and can be accessed with onetouch.

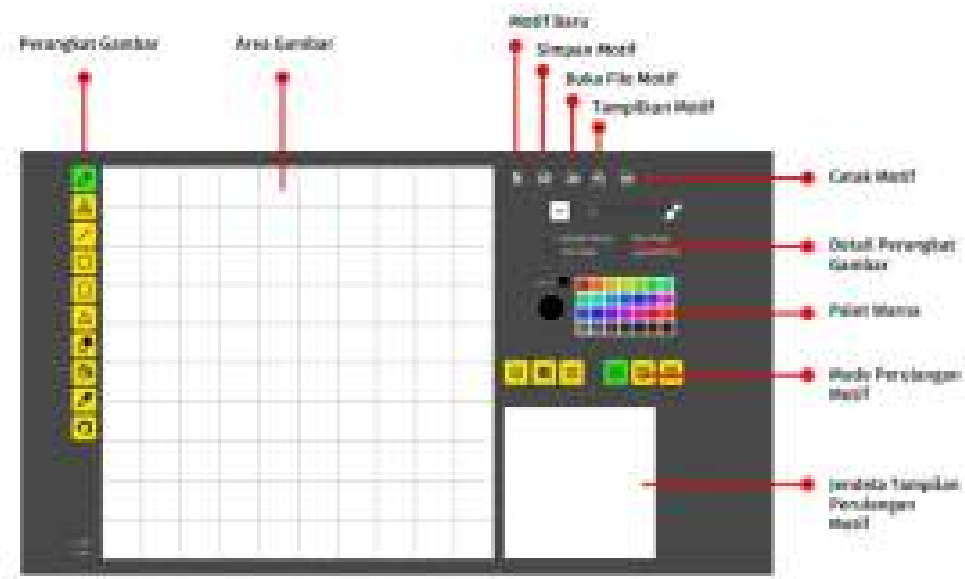

Fig 1. Screenshot of Dbatik and its Features

Line creation in D-batik adapts manual hand drawing techniques, which are combined withbezier curvealgorithms. These algorithms produce typical lines that are controlled according to the characteristics of traditional batik motifs. Examples of the lines produced and with this method are as follows:

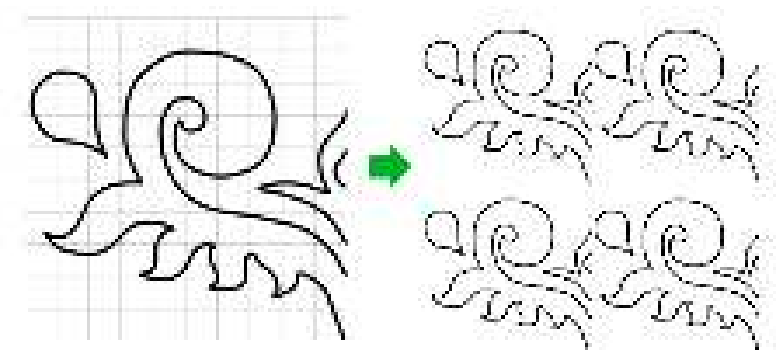

Fig 2. the results of the bezier curve method 
From the picture above, the results of the motifs produced by digital techniques have identical looks with the traditional techniques. The level of smoothness of lines that can be adjusted to the desired results by craftsmen by changing smoothness level. The other feature is the poly feature. In a number of batik motifs there are several techniques that uses the poly feature like "ceplok" motive. D-batik able to adapt the technique by repeating the curves of a number of desired angles. Examples of motives generated from these features are as follows:

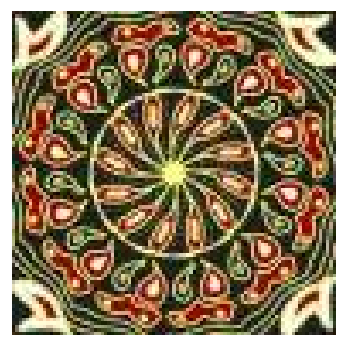

Fig 3. Curve line repetition feature ("ceplok" motif)

The next feature that adapted from conventional batik's motif creation is pattern repetition. Some existing repetition algorithms include normal repetition, repetitions with reflections, diagonal repetitions and diamond drop repetitions. The arrangement of repetitions is done simply by pressing the repetition button with the icons that match the desired results. Examples of repetition of motifs produced by these features are as follows:

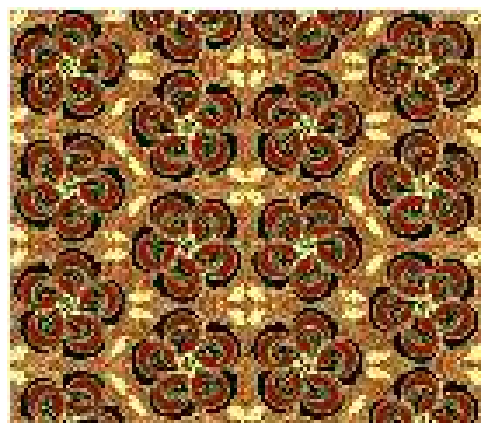

Fig 4. Motives generated from the repetition of patterns

Furthermore, to compare the effectiveness of using the D-batik application, a trial is conducted by comparing the length of time the motive was created. In a trial conducted on the subject of the study, it was found that the comparison of conventional batik motif development time using D-Batik software is shown in the following table. 
Table 1. Comparison of conventional and digital techniques in the length of the creation of batik motifs

\begin{tabular}{|c|c|c|c|c|c|}
\hline & & Mean & $\mathbf{N}$ & $\begin{array}{c}\text { Std. } \\
\text { Deviation }\end{array}$ & $\begin{array}{c}\text { Std. Error } \\
\text { Mean }\end{array}$ \\
\hline \multirow[t]{4}{*}{ Pair } & Conventional & 130.55 & 20 & 5.61 & 1.25 \\
\hline & Digital & 73.80 & 20 & 7.59 & 1.69 \\
\hline & \multicolumn{4}{|c|}{ Table 2. Paired Samples Correlations } & \\
\hline & & $\mathbf{N}$ & & & Sig. \\
\hline \multicolumn{2}{|c|}{$\begin{array}{c}\text { Pair - Conventional \& } \\
\text { Digital } \\
\end{array}$} & 20 & \multicolumn{2}{|c|}{0.173} & 0.466 \\
\hline
\end{tabular}

Table 3. Paired Samples Test (Paired Differences)

\begin{tabular}{llllllllc}
\hline \multicolumn{8}{c}{} & \multicolumn{7}{c}{$\begin{array}{c}\text { Confidence } \\
\text { Interval }\end{array}$} \\
\hline & Mean & $\begin{array}{l}\text { Std. } \\
\text { Deviation }\end{array}$ & $\begin{array}{l}\text { Std. Error } \\
\text { Mean }\end{array}$ & Lower & Upper & t & df & sig \\
\hline Pair 1 & 56.75 & 8.63 & 1.93 & 52.71 & 60.78 & 29.40 & 19 & 0.00 \\
\hline
\end{tabular}

Based on that data, the use of the D-batik application is able to accelerate the process of creating batik motifs significantly, where some manual techniques that require characteristics such as measurement and repetition of motifs are needed.

\section{Conclusion}

D-batik provides a new discourse on creating batik motifs digitally. Interactions that occur in D-batik applications are adapted fromthe conventional techniques and displayed in simple UI. The creation of batik motifs using digital techniques, proved to be able to accelerate the process of creating motifs, when compared to conventional techniques. The motives produced by digital methods have characteristics similar to conventional motifs, with a variety of repetitions. Further research on the social influence and behavior of craftsmen on D-batik applications is needed to deepen the penetration of technology towards traditional craftsmen. 


\section{References}

[1] Kemenprin, "Membangun Reputasi Batik Lewat Batik Mark", http://www.kemenperin.go.id/artikel/6122/Membangun-Reputasi-Batik-Lewat-BatikMark, 2007.

[2] Bifadlika, G., \& Russanti, I, Pengembangan Motif Batik Bondowoso di Perajin Batik Lumbung . "Jurnal Fakultas Teknik Unesa", 2016, 05(1), 30-31

[3] Adnyana, I. P. W., Kesiman, M. W. A., \& Seri, D. W., Pengembangan Aplikasi Pembuatan Pola Motif Batik dengan Menggunakan Pengolahan Citra Digital, "Jurnal Nasional Pendidikan Teknik Informatika", 2013,1(2), 20-27.

[4] Hsu, T.R., and Sinha, D.K., "Computer Aided Design: An Integrated Approach". West publishing company, Singapore, 2012.

[5] Wibisono, A, dan Toha, I.S., "Desain Batik Canting Cap Berbantuan Komputer". Proceeding Seminar Nasional Proses Produksi, Program Studi Teknik Industri Fakultas Teknologi Industri Universitas Atma Jaya Yogyakarta, 2001.

[6] Asmal, S., Subagyo, Wibisono, A., \& Sudiarso, A, "Pengembangan Sistem Cad (Computer Aided Design) Motif Batik Berbasis Karakter" in Proceeding Seminar Nasional IENACO, 2015, pp. 218-225.

[7] Wibawanto, W., \& Nugrahani, R, "Penelitian Kepada Masyarakat Pelatihan Pengembangan Motif Batik dengan Memanfaatkan Software Grafis bagi Pelaku Ikm Batik", Laporan Penelitian, Fakultas Bahasa Dan Seni UNNES, 2017.

[8] Liviu Despa, M, "Comparative Study on Software Development Methodo-logies". $\begin{array}{llll}\text { Database } & \text { Systems } & \text { Journal, } & \text { 5(3), }\end{array}$ https://doi.org/10.1109/MAHC.1983.10102.

[9] Tempo, "Indonesia Raksasa Teknologi Digital Asia", www.tempo.co/read/kolom/2015/10/02/2310/indonesia-raksasa-teknologi-digital-asia, 2019

[10] Thompson, Matt, "Digital Anthropology Group Is Happening Now". Savage Minds, 2012.

[11] Satori, Djam'an. "Metodologi Penelitian Kualitatif", Bandung : Alfabeta, 2007.

[12]Richards, G. and Wilson, J. "Developing creativity in tourist experiences: a solution to the serial repro-duction of culture", Tourism Management, 2006, 27(6),

[13]De Jong, J. P., \& Den Hartog, D. N, How Leaders Influence Employees' Innovative Behaviour". European Journal of Innovation Management, 10, 2007 p 41-64.

[14] Hamel, G., and C. K. Prahalad. "Competing For the Future". Boston : Harvard Business Scholl Press, 2011.

[15] Arymurthy, A. M., Nurhaida, I., \& Fanany, M. I, "Pengembangan Aplikasi Repositori Pengenalan Motif Batik Indonesia Berbasis Clustering Keypoint pada Ruang Hough", 2016. 